\title{
A historical novel with a difference
}

\begin{abstract}
Book Title:
In the shadow of the Galilean: The quest of the Historical Jesus in narrative form (translated from German by John Bowden: Der Schatten des Galiläers. Historische Jesusforschung in erzählender Form)
\end{abstract}

Book Cover:

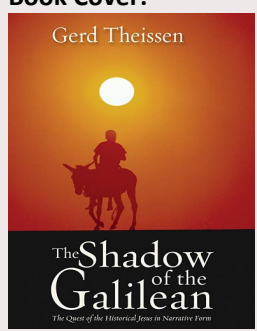

Author:

Gerd Theissen

ISBN:

9780800639006

Publisher:

Fortress, Minneapolis 2007

p. $212, \$ 15.83^{*}$

*Book price at time of Review

Review Title:

A historical novel with a

difference

Reviewer:

Gerda de Villiers ${ }^{1}$

\section{Affiliation:}

${ }^{1}$ Department of Old

Testament Studies,

University of Pretoria,

South Africa

Email:

gerda1.devilliers@up.ac.za

Postal address:

Department of Old

Testament Studies, Faculty

of Theology, University of

Pretoria, Pretoria 0002,

South Africa

C 2011. The Authors

Licensee: AOSIS

OpenJournals. This work

is licensed under the

Creative Commons

Attribution License.
The author, Gerd Theissen, is a renowned New Testament scholar whose field of expertise is the historical Jesus and the early church. In the shadow of the Galilean deals with the historical Jesus, not by means of an academic dissertation, but by using the age-old technique of story-telling, and writes a moving historical novel on the topic.

However, this is a historical novel with a difference. Theissen exploits the so-called literary device of 'focalisation' to the full. Who sees? Who tells? Two 'I'-narrators keep the reader spell-bound. In the first place, Theissen, as the author, is fully aware of the fact that he is living in a time far removed from the events that he is recounting. At the same time, his book is not fiction; much scholarly research on the topic is involved. Therefore, he has an imaginative mentor, Dr Kratzinger, to whom he submits the various chapters of his book. Kratzinger's objections and hesitations are dealt with by means of correspondence between Theissen and Kratzinger in a novel and very creative way, substituting the ever so boring discussions in the footnotes that one normally encounters in strictly academic publications. Thus writes Theissen on page 54 to Dr Kratzinger:

It dawned on me while writing that the conversations in this book reflect scholarly discussion more accurately than learned articles. In articles, after a great many pros and cons, the author presents the results as plausibly as possible - far more plausibly than they really are on the way from thought to point. By contrast, a narrative dialogue can remain open. No one has to have the last word. Which participant holds the truth is left vague.

In the second place, the main character is not Jesus, but Andreas, a contemporary and young Jewish grain merchant from a fairly liberal Hellenistic influenced background. Everything starts when he is captured by the Romans, and in exchange for his freedom, he has to spy on his own people. As a merchant, Andreas has contact with several people, he can travel all over the country, and enter into seemingly innocent discussions, without raising suspicion. Together with Andreas on his travels, the reader becomes aware of the different tendencies within Judaism of the 1st century AD: the Essenes, the Zealots, and the liberal Hellenists. From these groups, Andreas learns about Jesus. The Zealots do not like the glad tidings and peace Jesus brings, and the Romans fear that he is about to overturn their reign. In due course, Andreas feels him increasingly attracted to Jesus' teachings. In Jesus he recognises something of himself, a pawn being moved around by different groups that run the risk of extermination. Thus, in his reports about Jesus, he tries his best to present him to the Roman authorities as an itinerant philosopher and poet, thereby disguising his role as prophet.

Jesus and Andreas never meet: Andreas learns about Jesus through his shadow, as it were. In this regard, Theissen's own 'Afterword' (p. 181) is quite apt:

historical sources cannot give us the actual person but only a shadow of the historical reality. Using these shadows, historians attempt to break open the actual events ... We are stuck in the shadows of history, peering out at what we think is the truth.

The book contains an 'Appendix' with the most important sources on Jesus and his time, for example the Gospels and their sources, Josephus, Philo, the Qumran Writings and Tacitus. For the critical reader there are 'Notes' in every chapter to which he or she can refer to at the end of the book.

It is a pity that this book is only now translated into English, more than 20 years after its first publication in German. In the shadow of the Galilean by Gerd Theissen attests to high standing scholarly research, yet it is written in a style accessible to the lay person. It is highly recommended.

How to cite this book review: De Villiers, G., 2011, 'A historical novel with a difference', HTS Teologiese Studies/Theological Studies 67(3), Art. \#1135, 1 page. http://dx.doi.org/10.4102/hts.v67i3.1135 